Jurnal Ilmu Pertanian Agronitas Vol. 2 No.2 Edisi Oktober 2020

\title{
PEMBERIAN PUPUK MULTI MIKRO TERHADAP PERTUMBUHAN DAN PRODUKSI TANAMAN SELADA (Lactuca sativa L.) DALAM POLIBEG
}

\author{
Syafran Jali*1) \\ 1) Dosen Program Studi Agroteknologi Fakultas Pertanian Universitas Tamansiswa Palembang \\ ")Email: jalisyafran@gmail.com
}

\begin{abstract}
This study aimed to choose the right dose of multi-micro fertilizer for lettuce plants. This study used a completely randomized design (CRD) with the treatment of multi micro fertilizer $(\mathrm{M})$ as follows: $\mathrm{M} 1=25 \mathrm{~g}$ polybag-1, M2 = $50 \mathrm{~g}$ polybag- $1, \mathrm{M} 3=75 \mathrm{~g}$ polybag- 1 . The results showed that the dose treatment of $50 \mathrm{~g}$ polybag-1 showed the best results compared to the dose of $25 \mathrm{~g}$ polybag-1 and $75 \mathrm{~g}$ polybag-1 to the variable plant height, number of leaves and wet weight of the lettuce plant. The higher the dose of multi-micro fertilizer to the optimal limit of $50 \mathrm{~g}$ polybag-1, the higher the nutrient that is important for plants can be absorbed through the roots so that the growth and development of vegetative lettuce increases.
\end{abstract}

Keyword: lettuce, multi-micro fertilizer, dosage

\section{ABSTRAK}

Penelitian ini bertujuan untuk memilih takaran pupuk multi mikro yang tepat bagi tanaman selada. Penelitian ini menggunakan Rancangan Acak Lengkap (RAL) dengan perlakuan pupuk multi mikro (M) sebagai berikut: $\mathrm{M}_{1}=25 \mathrm{~g}_{\text {polibag- }}{ }^{-1}, \mathrm{M}_{2}=50 \mathrm{~g}$ polibag $^{-1}, \mathrm{M}_{3}=75 \mathrm{~g}$ polibag-1 ${ }^{-1}$. Hasil

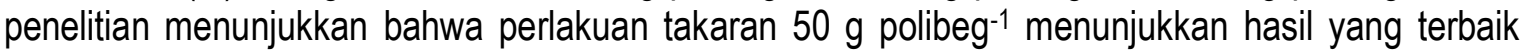
dibandingkan dengan takaran $25 \mathrm{~g}$ polibeg-1 dan $75 \mathrm{~g}^{-1}$ polibeg $^{-1}$ terhadap peubah tinggi tanaman, jumlah daun dan berat basah tanaman selada. Semakin tinggi takaran pupuk multi mikro sampai batas optimal $50 \mathrm{~g}_{\text {polibeg-1}}{ }^{-1}$, maka semakin tinggi unsur hara yang penting bagi tanaman dapat diabsorbsi melalui akar sehingga pertumbuhan dan perkembangan vegetatif tanaman selada semakin meningkat.

Kata kunci: selada, pupuk multi mikro, dosis

\section{PENDAHULUAN}

Usaha peningkatan produksi tanaman sayuran sangat penting untuk digalakan baik melalui pola ekstensif maupun intensif, sehingga dapat menopang kebutuhan gizi mayarakat dan sekaligus dapat meningkatkan pembangunan ekonomi melalui jalur ekspor non-migas. Salah satu tanaman yang bernilai ekonomis dan bergizi serta perlu untuk dinaikkan produksinya adalah selada (Lactuca sativa L.), karena tanaman ini merupakan salah satu tanaman sayuran yang mengandung vitamin A yang cukup tinggi (Sunaryono, 1990).

Permasalahan pokok yang dijumpai dalam upaya peningkatan gizi di negara kita adalah konsumsi protein yang rendah dan kekurangan vitamin A. Masalah kekurangan vitamin A dapat diatasi dengan peningkatan konsumsi sayuran hijau (Harjadi, 1979). Salah satu sayuran yang mengandung vitamin A yang cukup tinggi adalah sayuran selada. Selada (Lactuca sativa L.) merupakan tumbuhan daun yang dikonsumsi dalam keadaan segar sebagai lalapan atau penghias hidangan di pesta-pesta. Selada banyak mengandung vitamin A, B dan C 
(Sunaryono, 1990). Rukmana (1994) menambahkan bahwa, tanaman selada juga mengandung protein, lemak, karbohidrat dan mineral.

Menurut Rukmana (1994) dalam pembudidayaan selada dapat digunakan pupuk kandang untuk memenuhi kebutuhan hara selama pertumbuhannya. Pupuk kandang yang sering digunakan oleh petani adalah kotoran ayam. Kotoran ayam mengandung unsur hara $\mathrm{N} 1,00 \%, \mathrm{~K} \quad 0,4 \%$, air $0,55 \%$ dengan penambah an bahan organik juga dapat meningkatkan kesuburan tanah, memperbaiki mikro organisme tanah dan sifat fisik tanah seperti tekstur, struktur kerapatan (density), porositas, konsistensi, warna dan suhu, selain itu juga dapat mengikat air yang tinggi (Hakim et al., 1986).

Tanaman selama pertumbuhannya membutuhkan unsur hara nitrogen yang cukup tinggi. Adapun peranan $\mathrm{N}$ adalah merupakan penyusunan setiap sel hidup dan unsur ini juga merupakan bagian dari penyusun enzim dan molekul khlorofil (Setyamidjaja, 1986).

Perbaikan terhadap ketersediaan unsur hara secara umum dilakukan dengan memperbaiki kemasaman tanah, sehingga keseimbangan hara dapat terjadi secara optimal. Pada kondisi tertentu, teknologi budidaya juga mengaharuskan kita untuk menambah unsur hara tertentu ke dalam tanah untuk meningkatkan jumlahnya sesuai dengan komoditas yang ditanam. Pemupukan juga dapat dilakukan dengan melakukan penyemprotan campuran berbagai unsur hara ke daun, sehingga unsur hara tidak harus melalui perjalanan panjang dari akar ke daun, tetapi langsung dapat diserap daun dan dipakai dalam berbagai proses metabolisme.

Pemupukan hara makro pada tanaman selada telah dilaksanakan petani, namun produksi yang dicapai masih rendah dan pada keadaan tersebut banyak tanaman selada yang mengalami defisiensi hara mikro. Oleh karena sebagaian besar tanaman selada di tanam pada tanah podsolik merah kuning, dimana pada tanah tersebut menurut Adiningsih (1987) sangat kurang ketersediaan hara mikro bagi tanaman, maka penambahan hara mikro perlu dilakukan (Soepardi, 1987).

Penambahan hara mikro pada tanaman dapat diberikan melalui tanah dan atau daun (Black, 1980). Namun langkah yang dianggap praktis adalah melalui daun (Harjadi, 1979; Nyakpa et al., 1985 dan Soepardi, 1987). Keuntungan cara ini adalah hara mikro diserap lebih cepat oleh tanaman, sehingga hasil dari proses ini akan lebih cepat nampak. Selain itu uga cara ini dianggap cara yang mudah untuk mengurangi pengaruh dari fiksasi tanah dan kelembaban tanah yang rendah, dimana kedua faktor tersebut merupakan faktor penghambat tersedianya hara mikro bagi tanaman (Brady, 1984).

Hasil penelitian Muljeny (1986), menunjukkan bahwa pemberian pupuk melalui daun cenderung meningkatkan produksi sayuran selada terutama pada jumlah daun dan kandungan khlorofilnya.

Penelitian ini bertujuan untuk memilih takaran pupuk multi mikro yang tepat bagi tanaman selada.

\section{METODOLOGI PENELITIAN}

Penelitian telah dilaksanakan di rumah plastik Fakultas Pertanian Universitas Tamansiswa Palembang.

Bahan yang digunakan pada penelitian ini adalah benih selada, pupuk multi mikro, sekam padi, polibag dan fungsida Dithane M-45. Sedangkan alat yang digunakan adalah cangkul, ayakan tanah, mistar, ember, hand sprayer dan alat tulis.

\section{Metode Penelitian}

Penelitian ini menggunakan Rancangan Acak Lengkap (RAL) dengan perlakuan pupuk multi mikro (M) sebagai berikut:

$$
\begin{aligned}
& M_{1}=25 \text { g polibag- }^{-1} . \\
& M_{2}=50 \mathrm{~g} \mathrm{polibag}^{-1} . \\
& M_{3}=75 \mathrm{~g} \mathrm{polibag}^{-1} .
\end{aligned}
$$

Untuk mengolah data hasil penelitian, maka dilakukan analisis keragaman dengan 
membandingkan nilai $\mathrm{F}$ hitung dengan $\mathrm{F}$ tabel pada taraf $1 \%$.

\section{Prosedur Kerja}

\section{Persiapan media tanam}

Media tanam berupa tanah podsolik merah kuning yang diambil dari daerah Bukit Sangkal Palembang, sekam padi lalu dicampur menjadi satu sampai hamogen dengan perbandingan $3: 1$, kemudian ditambahkan pupuk multi mikro sesuai dengan perlakuan dan dibiarkan selama 1 minggu.

\section{Persemaian benih}

Persemaian benih selada dengan membuat bedengan yang berukuran $60 \times 30 \mathrm{~cm}$. Tanah dicangkul sedalam $20-30 \mathrm{~cm}$ dan digemburkan, lalu dibuat alur-alur. Benih selada ditabur tipis dan merata di sepanjang alur-alur, kemudian alur-alur tersebut ditutup dengan tanah secara tipis. Bibit sudah dapat dipindahkan ke polibag setelah berumur 15 hari atau berdaun dua. Pemindahan bibit dilakukan pada pagi hari.

\section{Penanaman}

Polibeg-polibeg yang sudah berisi media tanam disusun secara acak dengan jarak antara polibeg adalah $25 \times 25 \mathrm{~cm}$. Setiap polibeg ditanami 2 tanaman, hal ini dimaksudkan untuk menjaga jika salah satu bibit ada yang tidak tumbuh, maka bibit lainnya diharapkan tumbuh. Kemudian dilakukan penjarangan tanaman setelah tanaman berumur 1 minggu dan setiap polibeg dipelihara hanya 1 tanaman.

\section{Pemupukan}

Pemupukan tanaman selada yaitu pupuk multi mikro diberikan 1 minggu sebelum tanam. Setiap perlakuan diberikan pupuk multi mikro sesuai dengan takaran perlakuan yaitu: $M_{1}=25$ $\mathrm{g}_{\text {polibeg }}{ }^{-1}, \mathrm{M}_{2}=50 \mathrm{~g}_{\text {polibeg }}{ }^{-1}$ dan $\mathrm{M}_{3}=75 \mathrm{~g}$ polibeg-1.

\section{Pemeliharaan}

Pemeliharaan meliputi penyiraman dilakukan 1 kali sehari pada pagi hari. Penyiangan terhadap gulma yang tumbuh di sekitar tanaman selada bersamaan dengan pembumbunan tanah. Pengendalian penyakit dengan menggunakan fungisida Dithane M-45 dilakukan 1 minggu setelah tanam dengan menyemprotkan larutan fungisida pada tanaman.

\section{Panen}

Pemungutan hasil dilakukan setelah tanaman berumur 60 hari dengan ciri-ciri daun tampak hijau kekuningan dan hampir menyentuh tanah. Pemanenan dilakukan dengan cara mencabut seluruh bagian tanaman yaitu akar, batang dan daun.

\section{Peubah Yang Diamati}

1. Jumlah daun (helai). Jumlah daun dihitung setiap minggu dengan menghitung pertambahan daun pada tanaman dimulai satu helai daun dibawah titik tumbuh yang sudah membuka sempurna. Penghitungan dimulai pada minggu pertama setelah tanam sampai dengan panen.

2. Tinggi tanaman $(\mathbf{c m})$. Tinggi tanaman diukur seminggu sekali dimulai dari minggu pertama setelah penjarangan tanaman sampai dengan panen. Tinggi tanaman diukur dari leher akar sampai titik tumbuh tanaman.

3. Berat basah (g). Berat tanaman diukur pada waktu panen yaitu tanaman dicabut dengan hati-hati dan dibersihkan dari kotoran yang menempel pada tanaman, selanjutnya dicuci lalu ditiriskan dan ditimbang.

\section{HASIL DAN PEMBAHASAN}

\section{A. Hasil}

Berdasarkan hasil analisis keragaman masing-masing perlakuan terhadap peubah yang diamati sampai akhir penelitian dapat dilihat pada Tabel 2. 
Tabel 2. Pengaruh takaran pupuk multi mikro terhadap tinggi tanaman, jumlah daun dan berat basah tanaman selada.

\begin{tabular}{lcc}
\hline \multicolumn{1}{c}{ Peubah yang } & $\begin{array}{c}\text { Perlakuan } \\
\text { diamati }\end{array}$ & KK (\%) \\
\hline Tinggi tanaman (cm) & ${ }^{* *}$ & 5,56 \\
Jumlah daun (helai) & ${ }^{* *}$ & 9,45 \\
Berat basah (g) & ${ }^{* *}$ & 1,93 \\
\hline
\end{tabular}

$$
\text { Keterangan: } \begin{aligned}
M & =\text { Pupuk multi mikro } \\
\mathrm{KK} & =\text { Koefisien Keragaman } \\
& =\text { Berpengaruh sangat nyata }
\end{aligned}
$$

\section{Tinggi tanaman $(\mathrm{cm})$}

Perkembangan pertumbuhan tinggi tanaman dari minggu ke satu sampai minggu ke lima disajikan pada Gambar 1.

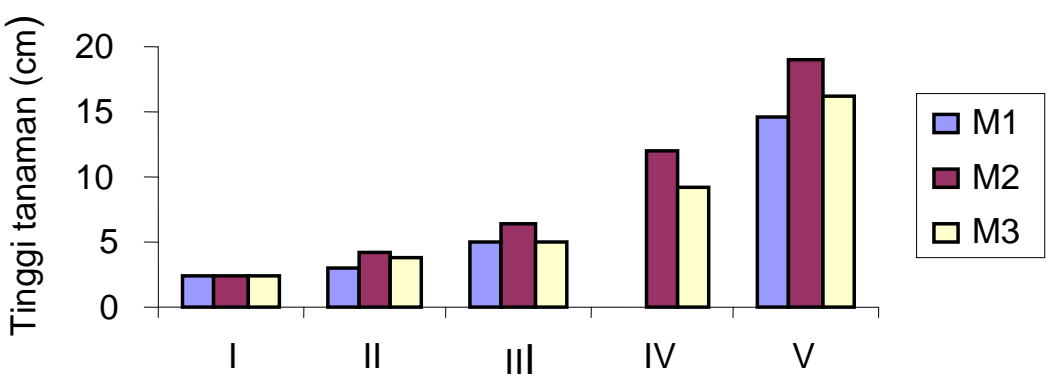

Minggu ke

Gambar 1. Grafik pertumbuhan tinggi tanaman dari minggu ke satu sampai minggu ke lima

Hasil analisis keragaman menunjukkan bahwa perlakuan takaran pupuk multi mikro berpengaruh sangat nyata terhadap tinggi tanaman selada. Hasil uji BNT perlakuan takaran pupuk multi mikro terhadap tinggi tanaman selada pengamatan minggu ke lima disajikan pada Tabel 3.

Tabel 3. Pengaruh takaran pupuk multi mikro terhadap tinggi tanaman pada minggu ke 5.

\begin{tabular}{ccc}
\hline $\begin{array}{c}\text { Perlakuan (g } \\
\left.\text { polibeg }^{-1}\right)\end{array}$ & Rerata (cm) & $\begin{array}{c}\text { BNT 0,01 } \\
(1,80)\end{array}$ \\
\hline 25 & 14,51 & $\mathrm{~B}$ \\
50 & 18,91 & $\mathrm{~A}$ \\
75 & 16,29 & $\mathrm{AB}$ \\
\hline
\end{tabular}

Keterangan: angka yang diikuti oleh huruf yang sama berarti berbeda tidak nyata pada taraf uji 0,01 .
Perlakuan dengan takaran pupuk multi mikro $50 \mathrm{~g}$ polibeg-1 memberikan hasil terbaik yaitu $18,91 \mathrm{~cm}$, namun berdasarkan hasil uji statistik perlakuan takaran pupuk multi mikro 50

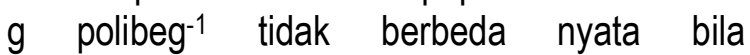
dibandingkan dengan takaran $75 \mathrm{~g}$ polibeg- $^{-1}$, walaupun nilai untuk takaran $75 \mathrm{~g}$ polibeg-1 lebih tinggi yaitu $16,29 \mathrm{~cm}$.

\section{Jumlah daun (helai)}

Perkembangan pertumbuhan tinggi tanaman dari minggu ke satu sampai minggu ke lima disajikan pada Gambar 2. Hasil analisis keragaman menunjukkan bahwa perlakuan takaran pupuk multi mikro berpengaruh sangat nyata terhadap jumlah daun tanaman selada. 


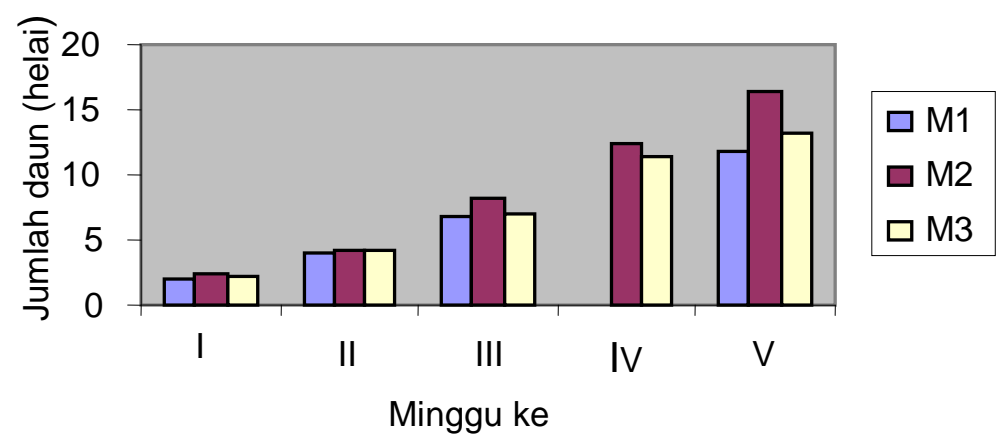

Gambar 2. Grafik pertumbuhan jumlah daun dari minggu ke satu sampai minggu ke lima

Hasil uji BNT perlakuan takaran pupuk multi mikro terhadap jumlah daun tanaman pengamatan minggu ke lima selada disajkan pada Tabel 4.

Tabel 4. Pengaruh takaran pupuk multi mikro terhadap jumlah daun pada minggu ke 5 .

\begin{tabular}{ccc}
\hline $\begin{array}{c}\text { Perlakuan (g } \\
\left.\text { polibeg- }^{-1}\right)\end{array}$ & Rerata (helai) & $\begin{array}{c}\text { BNT 0,01 } \\
(1,96)\end{array}$ \\
\hline 25 & 11,88 & A \\
50 & 16,44 & A \\
75 & 13,22 & B \\
\hline
\end{tabular}

Keterangan: angka yang diikuti oleh huruf yang sama berarti berbeda tidak nyata pada taraf uji 0,01 .

Perlakuan dengan takaran pupuk multi mikro $50 \mathrm{~g}$ polibeg-1 $^{-1}$ memberikan hasil terbaik yaitu $16,44 \mathrm{~cm}$, namun berdasarkan hasil uji statistik perlakuan takaran pupuk multi mikro 50 g polibeg- $^{-1}$ tidak berbeda nyata bila dibandingkan dengan takaran $75 \mathrm{~g}^{\text {polibeg- }}{ }^{-1}$, walaupun nilai untuk takaran $75 \mathrm{~g}$ polibeg-1 lebih tinggi yaitu $13,22 \mathrm{~cm}$.

\section{Berat basah (g)}

Hasil analisis keragaman menunjukkan bahwa perlakuan takaran pupuk multi mikro berpengaruh sangat nyata terhadap berat basah tanaman selada. Hasil uji BNT perlakuan takaran pupuk multi mikro terhadap berat basah tanaman selada disajikan pada Tabel 5 .

Tabel 5. Pengaruh takaran pupuk multi mikro terhadap berat basah $(\mathrm{g})$.

\begin{tabular}{ccc}
\hline $\begin{array}{c}\text { Perlakuan (g } \\
\left.\text { polibeg }^{-1}\right)\end{array}$ & Rerata $(\mathrm{g})$ & $\begin{array}{c}\text { BNT 0,01 } \\
(4,02)\end{array}$ \\
\hline 25 & 98,61 & $\mathrm{~A}$ \\
50 & 112,26 & $\mathrm{~B}$ \\
75 & 105,16 & $\mathrm{C}$ \\
\hline Keterangan: angka yang diikuti oleh huruf yang \\
\multicolumn{3}{c}{ sama berarti berbeda tidak nyata } \\
pada taraf uji $0,01$.
\end{tabular}

Pada Tabel 5 dapat dilihat bahwa perlakuan takaran pupuk multi mikro $50 \mathrm{~g}$ polibeg-1 $^{-1}$ memberikan hasil terbaik yaitu sebesar $112,26 \mathrm{~g}$ berat basah, walaupun perlakuan takaran pupuk multi mikro sebanyak $75 \mathrm{~g}$ polibeg $^{-1}$, menunjukkan hasil yang tertinggi yaitu sebesar $105,16 \mathrm{~g}$ berat basah.

\section{B. Pembahasan}

Berdasarkan hasil analisis keragaman terlihat bahwa perlakuan takaran pupuk multi mikro berpengaruh sangat nyata terhadap peubah tinggi tanaman, jumlah daun dan berat basah tanaman selada. Hasil uji BNT pada Tabel 3, 4 dan 5 terlihat bahwa perlakuan takaran $50 \mathrm{~g}^{\text {polibeg- }}{ }^{-1}$ menunjukkan hasil yang terbaik dibandingkan dengan takaran $25 \mathrm{~g}$ polibeg $^{-1}$ dan $75 \mathrm{~g}^{\text {polibeg-1 }}{ }^{-1}$ terhadap peubah 
tinggi tanaman, jumlah daun dan berat basah tanaman selada.

Semakin tinggi takaran pupuk multi mikro sampai batas optimal $50 \mathrm{~g}^{\text {polibeg }}{ }^{-1}$, maka semakin tinggi unsur hara yang penting bagi tanaman dapat diabsorbsi melalui akar sehingga pertumbuhan dan perkembangan vegetatif tanaman selada semakin meningkat.

Pada tanaman tingkat tinggi, unsur hara yang ada dalam larutan tanah diserap oleh akar sebagian besar melalui rambut akar (bulu akar) (Agustina, 1990). Pergerakan unsur hara ke permukaan akar melalui tiga cara yaitu intersepsi (penyerapan) akar, aliran masa dan difusi (Hakim et al., 1986). Setelah ion-ion berada dalam xylem, kemudian ion-ion tersebut akan diangkut ke daun melalui gabungan xylem pada batang sampai ke mesofil daun (Agustina, 1990).

Semakin tinggi takaran pupuk multi mikro yang diberikan sampai batas optimal, maka unsur hara yang dapat diabsorbsi juga semakin banyak. Berarti pembentukan khlorofil di dalam kloroplast juga optimal yang secara tidak langsung akan mengoptimalkan laju proses fotosintesis, laju respirasi dan laju metabolisme lainnya termasuk proses pembelahan sel yang akan membentuk sel-sel baru.

Takaran pupuk multi mikro dibawah batas optimal akan memberikan hasil yang lebih rendah dibandingkan takaran pupuk dengan batas optimal. Akibatnya pembentukan khlorofil, laju fotosintesis, laju respirasi dan laju metabolisme lainnya termasuk pembelahan dan pembentukan sel akan menurun. Berarti secara tidak langsung hasil dari peubah yang diamati akan menunjukkan hasil yang rendah dibandingkan takaran pupuk multimikro yang optimal. Sedangkan pada takaran di atas batas optimal juga cenderung memberikan hasil yang kurang baik bagi pertumbuhan dan perkembangan vegetatif tanaman selada.

\section{KESIMPULAN}

Berdasarkan hasil penelitian dapat disimpulkan bahwa pemberian pupuk multi mikro berpengaruh baik terhadap pertumbuhan dan produksi tanaman selada.

\section{DAFTAR PUSTAKA}

Agustina, L. 1990. Dasar Nutrisi Tanaman. Rineka Cipta. Jakarta.

Bostomi. 1984. Tanaman Sayur-sayuran Daerah Tropis. Fakultas Pertanian Universitas Andalas. Padang.

Edmond, J.B., T.L. Sen., F.S. Endrews and R.G. Halfance. 1975. Foundamentals of Horticuture. Tta Mc. Graw Hill Publishing Company LTD. New Delhi.

Gomez, A and A. Gomez. 1976. Statistical Prosedure For Agriculture Research Emphais no Rice?

Hakim, N., M.Y. Nyakpa., A.m. Lubis., S.G. Nugroho., M.A. Diha., Go Ban Hong dan H.H. Bailey. 1986. Dasar-dasar IImu Tanah. Universitas Lampung. Lampung.

Harjadi, S.S. 1979. Pengantar Agronomi. Gramedia. Jakarta.

Haryanto, E., T. Suhartini dan E. Rahayu. 1995. Sawi dan Selada. Penebar Swadaya. Jakarta.

Lakitan, B. 1993. Dasar-dasar Fisiologi Tumbuhan. Fakultas Pertanian Universitas Sriwijaya. Palembang.

Lingga, P. 1992. Petunjuk Penggunaan Pupuk. Penebar Swadaya. Jakarta.

Muljeny, S. 1986. Pengaruh Pemberian Berbagai Jenis Pupuk Melalui Daun Terhadap Produksi Tanaman Selada (Lactuca sativa L.). Fakultas Pertanian Universitas Sriwijaya. Palembang. (Tidak dipublikasikan).

Nazaruddin. 1994. Budidaya dan Pengaturan Panen Sayuran Dataran Rendah. Penebar Swadaya. Jakarta. 
Nyakpa, M.Y., A.M. Lubis., M.A. Pulung., A.g. Rukmana, R. 1994. Bertanam Selada dan Andewi. Amrah. 1985. Kesuburan Tanah. Universitas Lampung. Lampung.

Palungkun dan Asiani. 1993. Sayuran Komersial. Penebar Swadaya. Jakarta.

Pracaya. 2002. Bertanam Sayuran Organik Di Kebun, Pot dan Polibag. Penebar Swadaya. Jakarta.

Prawiranata, W., S. Harran dan P. Tjondronegoro. 1986. Dasar-dasar Fisiologi Tumbuhan Jilid II. Departemen Botani. Fakultas Pertanian Institut Pertanian Bogor. Bogor.

Rochitun dan Sumarno. 1991. Budidaya Tanaman Tropika. Penerbit Kanisius. Yogyakarta.

Sarief, E.S. 1986. IImu Tanah Pertanian. Pustaka Buana. Bandung.

Setyamidjaja, D. 1986. Pupuk dan Pemupukan. Simplex. Jakarta.

Sunaryono, H. 1990. Kunci Bercocok Tanam Sayursayuran Penting di Indonesia. (Produksi Hortikultura II). Sinar Bandung. Bandung.

Supriatna,I.S. 1996. Menanam dan Mengolah Selada Sejuta Rasa. Aneka. Solo.

Widarto, L. 1994. Vertikultura, Bercocok Tanam Secara Bertingkat. Penebar Swadaya. Jakarta. 